\title{
Rate and efficiency of yolk utilization in developing eggs of the sole Solea solea
}

\author{
J. Flüchter and T. J. Pandian \\ Biologische Anstalt Helgoland, Meeresstation, Helgoland
}

KURZFASSUNG: Rate und Quote der Dotterausnutzung bei sich entwickelnden Eiern der Seezunge Solea solea. Wie bei anderen planktisch-marinen Fischen sind die Eier der Seezunge durch einen relativ hohen Wassergehalt $(91 \%)$ und einen niedrigen Kaloriengehalt $(5800 \mathrm{cal} / \mathrm{g}$ trockene organische Substanz) charakterisiert; demgegenüber haben die Eier der Substratlaicher einen niedrigeren Wassergehalt (etwa $75 \%$ ) und einen höheren Kaloriengehalt $(6500 \mathrm{cal} / \mathrm{g}$ trockene organische Substanz). Seezungenlarven scheiden kurz vor und nach dem Schlüpfen Schleim aus, wenn sie in destilliertes Wasser überführt werden. Diese Schleimabsonderung stört die Bestimmung des Trockengewichts und des Kaloriengehalts. Sie kann reduziert werden, wenn man die Larven vor Überführung in destilliertes Wasser mit Formalin abtötet. Die Ausnutzungsquote des Dotters frischgeschlüpfter Larven beträgt im Mittel $85,2 \%$ bei $10^{\circ} \mathrm{C}, 79,0 \%$ bei $15^{\circ} \mathrm{C}$ und $75,5 \%$ bei $20^{\circ} \mathrm{C}$. Die Inkubationsdauer beläuft sich auf etwa 176 Stunden bei $10^{\circ} \mathrm{C}, 80$ Stunden bei $15^{\circ} \mathrm{C}$ und 53 Stunden bei $20^{\circ} \mathrm{C}$.

\section{INTRODUCTION}

Our knowledge on rate and efficiency of yolk utilization in developing fish eggs has been summarized by $S_{M r T H}(1957,1958)$. The information so far available is, however, based mostly on freshwater fishes. Of the four papers available on marine fishes, the one by Blaxter \& Hempel (1966) deals with Clupea harengus, while two others by Dakin \& Dakin (1925 quoted in NeEdHam 1931, p. 1114) and Ryland \& Nichols (1967) concern Pleuronectes platessa. The authors studied the utilization of yolk by measuring the length and dry weight of the embryo or the concentration of nitrogen in the embryo. LASKER (1962), using developing eggs of Sardinops caerulea, analyzed yolk and larvae for water, protein and calorific contents, measured oxygen consumption of developing larvae, and reported on rate and efficiency of yolk utilization. The present paper deals with the calorific content of the egg, and rate and efficiency of yolk utilization in relation to temperature in developing eggs of Solea

\section{MATERIAL AND METHODS}

The eggs used in the present study were collected from spawning North Sea soles Solea solea (about 6 year old fishes) maintained in the laboratory for 3 years. The 
swimming eggs were collected immediately after spawning and allowed to develop in small aquarium cylinders kept in temperature-constant rooms. At desired intervals, the developing eggs were removed for further analyses.

A definite number (about 300) of developing eggs was counted, washed free from adhering sea water by exposing them to distilled water for a period of 3 minutes, and weighed and dried at $80^{\circ} \mathrm{C}$ for 4 hours. Ash content was estimated by incinerating the sample at $500^{\circ} \mathrm{C}$ for 5 hours. Calorific measurements were made with a semimicro bomb calorimeter (Parr Instrument Co., Model No. 1412). All weighings were made using a Sartorius balance sensitive to $\pm 0.01 \mathrm{mg}$.

\section{RESULTS}

\section{Composition of fresh eggs}

Fresh eggs were collected on March 16 and March 29, 1967. On both dates water temperature at spawning was $8^{\circ} \mathrm{C}$. A portion of the eggs from March 16 was incubated at $10^{\circ} \pm 0.1^{\circ} \mathrm{C}$; the rest were analyzed immediately. The eggs from March 29 were incubated at $15^{\circ}$ and $20^{\circ} \pm 0.1^{\circ} \mathrm{C}$.

The values obtained for dry weight, ash and calorific contents are presented in Table 1. Dry weight amounted to $9.2 \%$ of the living matter, ash to $1.16 \%$ of the dry matter, and calorific content to $5836 \mathrm{cal} / \mathrm{g}$ dry organic substance.

\section{Table 1}

Composition of fresh eggs of the sole Solea solea. The value on dry weight content of the eggs is based on 4322 eggs (14 groups of about 300 eggs each); standard deviation is related to the mean value of the 14 mean values

\begin{tabular}{|c|c|c|c|c|}
\hline $\begin{array}{l}\text { Determinations made } \\
\text { Number Kind }\end{array}$ & $\begin{array}{l}\text { Mean } \\
\text { values }\end{array}$ & $\begin{array}{l}\text { Standard } \\
\text { deviation }\end{array}$ & $\begin{array}{l}\text { Coefficient } \\
\text { of variation }\end{array}$ & $\begin{array}{l}\text { Average } \\
\text { values for } \\
\text { a single egg }\end{array}$ \\
\hline $\begin{array}{l}\text { Dry weight } \\
\text { Ash content } \\
\text { Energy (cal/g } \\
\text { organic substance) }\end{array}$ & $\begin{array}{l}9.2 \% \% \\
1.16 \% \\
5836\end{array}$ & $\begin{array}{l} \pm 0.31 \\
\pm 0.1 \\
\pm 61\end{array}$ & $\begin{array}{l}3.4 \% \\
0.9 \% \\
1.0 \%\end{array}$ & $\begin{array}{c}84.2 \mu \mathrm{g} \\
1.0 \mu \mathrm{g} \\
0.486 \mathrm{cal}\end{array}$ \\
\hline
\end{tabular}

Of 100 randomly chosen eggs, the diameter of an egg measured to $1.3 \mathrm{~mm}$ in 95 individuals, while 4 of them measured to $1.2 \mathrm{~mm}$ and the other $1.4 \mathrm{~mm}$. A total number of 4322 eggs collected on two different dates was used to estimate the dry weight of a single egg. The mean dry weight value of a single egg was $83.0 \mu \mathrm{g}$ for the March 16 material and $88.8 \mu \mathrm{g}$ for the March 29 material. Values obtained on both series (14 determinations) averaged $84.2 \mu \mathrm{g}( \pm 1.3 \mu \mathrm{g})$ with a coefficient of variation of $1.5 \%$ from the mean value. Using the value of $84.2 \mu \mathrm{g} / \mathrm{egg}$ together with the data presented in Table 1, live $(915.2 \mu \mathrm{g})$ and dry weights and ash and calorific contents of a single egg were calculated. 
Initially, composition of eggs was studied without washing them in distilled water prior to weighing. After 4 hours drying, sea water adhering to the surface of the eggs evaporated, leaving considerable quantities of salt particles. Analyses of such material gave $20.14 \%$ ash and $4513 \mathrm{cal} / \mathrm{g}$ dry weight, against $1.16 \%$ ash and $5768 \mathrm{cal} / \mathrm{g} \mathrm{dry}$ weight in washed eggs (Table 1). Thus, later on all eggs were washed for 3 minutes in distilled water prior to drying.

Fresh eggs or developing eggs (up to the primitive streak formation stage) showed no other side effect upon distilled water treatment. As soon as more advanced developmental stages were brought in contact with distilled water at temperatures between $10^{\circ}$ and $20^{\circ} \mathrm{C}$, the embryos secreted a jelly-like slime substance in large quantities even if exposure time was only 1 minute. This slime substance increased the weight of the test material considerably; at the same time it reduced the calorific value to less than $2000 \mathrm{cal} / \mathrm{g}$ dry weight (5 determinations). Four determinations of ash content of such substances $\left(600^{\circ} \mathrm{C}\right)$ gave values of more than $40 \%$; the ash was lead black in color. In the bomb calorimeter the substance remained charred and uncombusted. Upon drying, the slime secreted by the embryos became so inert that it could neither be reduced to ash after a period of 6 hours incineration at $600^{\circ} \mathrm{C}$, nor be combusted in the bomb calorimeter. Due to these unexpected difficulties, much of our precious material was lost and it was subsequently found that slime secretion could be reduced to a considerable extent by killing the larvae or embryos in $5 \%$ sea water formalin prior to distilled water exposure. However, we had only limited material and the results on efficiency of yolk utilization based on a few values only.

\section{Efficiency of yolk utilization}

Average changes in dry weight and calorific content of a single egg are given in Table 2 . At $10^{\circ} \mathrm{C}$, a freshly hatched larva $(67.4 \mu \mathrm{g}$ dry weight) contains $0.414 \mathrm{cal}$, i. e.

Table 2

Average changes in dry weight and calorific content of developing eggs and freshly hatched larvae of the sole Solea solea. The values presented are based on two determinations each

\begin{tabular}{|lccccc|}
\hline $\begin{array}{l}\text { Developmental } \\
\text { stage }\end{array}$ & $\begin{array}{c}\text { cal/g dry } \\
\text { weight }\end{array}$ & $\begin{array}{c}\text { cal/g dry } \\
\text { organic } \\
\text { substance }\end{array}$ & $\begin{array}{c}\text { Number of } \\
\text { eggs or } \\
\text { larvae } \\
\text { counted }\end{array}$ & $\begin{array}{c}\text { Average dry } \\
\text { weight of } \\
\text { one egg or } \\
\text { larva }(\mu \mathrm{g})\end{array}$ & $\begin{array}{c}\text { Average } \\
\text { cal/egg } \\
\text { or } \\
\text { cal/larva }\end{array}$ \\
\hline $\begin{array}{l}\text { Fresh egg }\left(8^{\circ} \mathrm{C}\right) \\
\text { "Primitive streak" }\end{array}$ & 5768 & 5836 & 4322 & 84.2 & 0.486 \\
$\left(10^{\circ} \mathrm{C}\right)$ & 5748 & - & 800 & 78.5 & 0.451 \\
Just before hatching & 5772 & - & 660 & 72.7 & 0.420 \\
$\left(10^{\circ} \mathrm{C}\right)$ & 6145 & 6496 & 800 & 67.4 & 0.414 \\
Just hatched $\left(10^{\circ} \mathrm{C}\right)$ & - & 450 & 63.1 & 0.384 \\
Just hatched $\left(15^{\circ} \mathrm{C}\right)$ & 6058 & 6169 & 600 & 60.4 & 0.367 \\
\hline Just hatched $\left(20^{\circ} \mathrm{C}\right)$ & 6022 & & & & \\
\hline
\end{tabular}


about $85.2 \%$ of the total energy contained in the fresh egg. The corresponding values for larvae hatched at $15^{\circ}$ and $20^{\circ} \mathrm{C}$ were $79.0 \%$ and $75.5 \%$, respectively.

Freshly hatched larvae contained considerable quantities of yolk; therefore, the values stated above require correction for the yolk content. In other species such as herring it has been possible to dissect out the yolk mass from the embryo (BLAXTER \& Hempel 1966, Pafrenhöfer \& Rosenthal 1968). However, the larva of the sole is small $(2.6 \mathrm{~mm})$ and delicate, and removal of yolk by dissection could introduce considerable errors. In general, the yolk mass was elliptical in shape. A number of larvae were measured for the lengths and breadths of their yolk masses; and the average volume of the yolk mass was estimated from 41 values. Assuming the specific gravity value of the marine planktonic eggs of the plaice Pleuronectes platessa (SмiтH 1957, p. 330) to be similar to that of the eggs of the sole S. solea, the volume of the yolk mass contained in the freshly hatched larva was converted into wet weight $(495 \mu \mathrm{g})$. There is much evidence to show that water (GRAY 1926) and calorific content per unit weight (LASKER 1962) of the yolk do not change during embryonic development. Thus, using the calorific content and water values obtained for fresh eggs, the calorific content of unused yolk mass in a single fresh hatched larva has been estimated to be $0.262 \mathrm{cal}$.

Since the yolk volume varied only a little in larvae hatched at different temperatures, the calorific value obtained for the yolk mass of a freshly hatched larva at $10^{\circ} \mathrm{C}$ was used for the larvae hatched at $15^{\circ}$ and $20^{\circ} \mathrm{C}$.

On the basis of these considerations the following values were estimated: at hatching, a single larva contains (without yolk mass) $0.152 \mathrm{cal}$ at $10^{\circ} \mathrm{C}, 0.122 \mathrm{cal}$ at $15^{\circ} \mathrm{C}$ and $0.105 \mathrm{cal}$ at $20^{\circ} \mathrm{C}$; i. e., of the $0.224 \mathrm{cal}$ used during the embryonic development (till hatching), substances containing only $0.152 \mathrm{cal}, 0.122 \mathrm{cal}$ or $0.105 \mathrm{cal}$ were utilized by the embryos at these different temperaturs. Thus, the net utilization efficiency values are $67.9 \%, 54.5 \%$ or $46.9 \%$ at the 3 temperatures.

Table 3

Effects of different temperature levels on the embryonic development of Solea solea

\begin{tabular}{|c|c|}
\hline Temperature $\left({ }^{\circ} \mathrm{C}\right)$ & \multicolumn{1}{c}{ Observations } \\
\hline 4 & $\begin{array}{l}\text { Cell division leads to beginning embryonic disc stage; no further } \\
\text { development }\end{array}$ \\
5 & $\begin{array}{l}\text { Embryonic disc is formed and covers } 2 / 3 \text { of the egg surface; no further } \\
\text { development }\end{array}$ \\
6 & $\begin{array}{l}\text { Embryo develops up to "primitive streak" stage; no further develop- } \\
\text { ment }\end{array}$ \\
7 & $\begin{array}{l}\text { Full normal development; } 50 \% \text { of the eggs hatched on the } 12 \text { th day } \\
\text { following fertilization }\end{array}$ \\
10 & $\begin{array}{l}\text { Full embryonic disc is formed at } 57 \text { th hour after fertilization; after } \\
75 \text { hours: formation of primitive streak; after } 176: 50 \% \text { of the tested } \\
\text { eggs hatched } \\
\text { After } 25 \text { hours: embryonic disc covers } 1 / 2 \text { of the egg surface; after } \\
40 \text { hours: formation of embryonic disc is completed; after } 80 \text { hours: } \\
50 \% \text { of the tested eggs hatched } \\
\text { Development is very fast; after } 53 \text { hours } 50 \% \text { of eggs hatched }\end{array}$ \\
20 &
\end{tabular}




\section{Rate of yolk utilization}

The effects of temperature on the rate of embryonic development have been summarized in Table 3. These observations relate to material collected in 1966 and 1967; they have, in part, been presented by Flüchter (1966). At the low temperature levels $4^{0}, 5^{\circ}$ and $6^{\circ} \mathrm{C}$, egg development became arrested at different early stages. At the higher temperature levels full normal development took place. At $7^{\circ} \mathrm{C}, 50 \%$ of the larvae hatched after 12 days, at $20^{\circ} \mathrm{C}$ after 53 hours. All the other data can be seen from Table 3.

As has already been shown, as much as 0.152 cal have been utilized by a larva hatching at $10^{\circ} \mathrm{C}$. This amount of energy was converted into embryonic substance during a period of about 176 hours. The respective values are $0.122 \mathrm{cal} / 80$ hours at $15^{\circ} \mathrm{C}$ and $0.105 \mathrm{cal} / 53$ hours at $20^{\circ} \mathrm{C}$.

\section{DISCUSSION}

The data on composition of fresh fish eggs available in the literature have been summarized in Table 4. Data on calorific content of fish eggs are scanty; therefore, we have calculated the calorific values from the data reported by DAKIN \& DAKIN (1925, quoted in Needham 1931, p. 1114), Hollet \& Hayes (1946), Hartmann et al. (1947) and MENGr (1965) on chemical composition of eggs. The values $9400 \mathrm{cal} / \mathrm{g}$ fat, $5650 \mathrm{cal} / \mathrm{g}$ protein, $4150 \mathrm{cal} / \mathrm{g}$ carbohydrate (MaYNARD \& LoosLI 1962, p. 322) and $4187 \mathrm{cal} / \mathrm{g}$ dry egg membrane (FAustov \& ZotIN 1964) were used to convert the values on chemical composition into calorific content. Having a high percentage of water content $(91 \%)$ and low calorific content $(5836 \mathrm{cal} / \mathrm{g}$ dry organic substance), the eggs of Solea solea from the North Sea closely resemble those of the Atlantic plaice Pleuronectes platessa (DAKIN \& DAKIN 1925), the Pacific sardine Sardinops caerulea (LAsker 1962), and the Baltic cod Gadus morbua (Mengi 1965). High water content and small size may be considered a special adaptation to pelagic life (SvERDrup et al. 1964, p. 821). While the planktonic eggs of these four marine species have a calorific value of about $5800 \mathrm{cal} / \mathrm{g}$ dry organic substance, demersal eggs of either marine fishes - e. g., Clupea harengus (PAFFenhö̈ER \& Rosenthal 1968) - or anadromus (euryhaline) fresh water fishes - e. g., Salmo (Hollet \& Hayes 1946, Hartmann et al. 1947), Acipenser spp. (Faustov \& Zotin 1964) - have more than $6200 \mathrm{cal} / \mathrm{g}$ weight (ash $5 \%$ ) or $6500 \mathrm{cal} / \mathrm{g}$ dry organic substance. A relatively higher calorific content per unit egg weight indicates a higher fat content. A high fat content in demersal fish eggs should not be misunderstood; the fat content in fish eggs has little to do with floatation, which is brought about by reducing the specific gravity of the planktonic eggs of the demersal fishes (SMrтH 1957, p. 330).

The developing eggs of Solea solea, which were not affected by exposure to distilled water during early development, secreted large quantities of slime when exposed to distilled water after having reached the primitive streak formation stage. It is possible that, at this stage, the permeability of the egg membrane increases. PANDIAN (1968) observed that exposure of developing eggs of the slipper limpet Crepidula fornicata to distilled water also induced slime secretion. However, reducing 


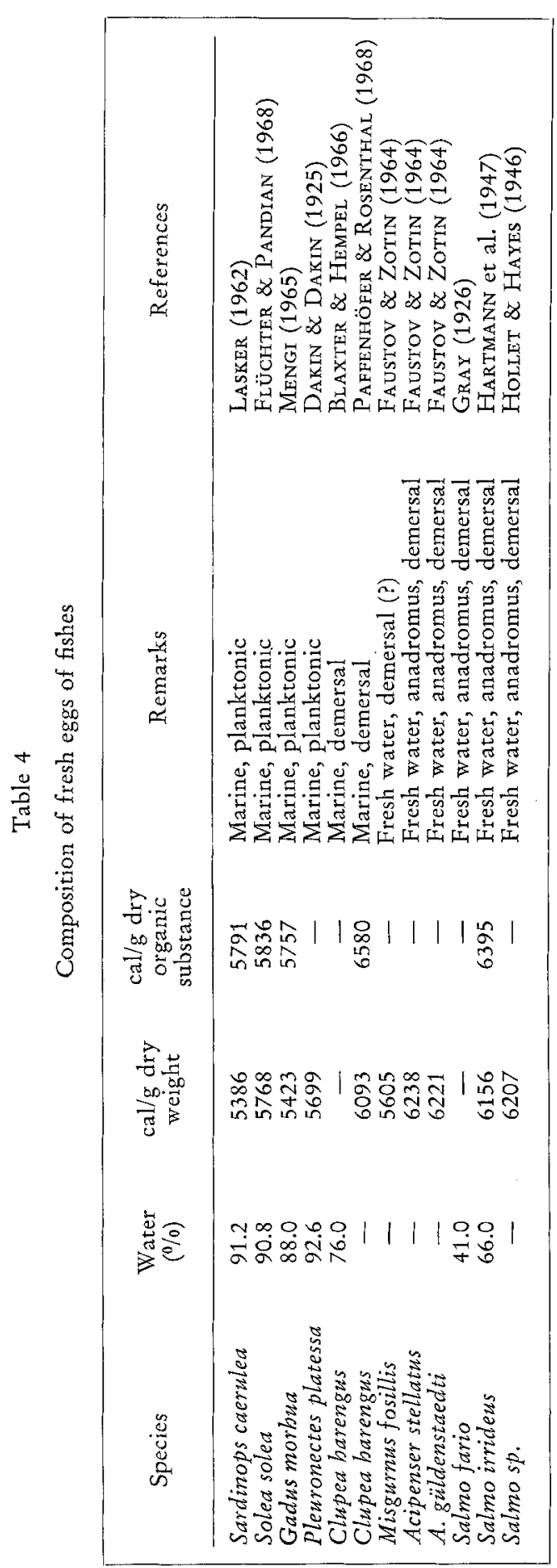


the duration of exposure to less than 15 seconds, the slime produced could be minimized to a negligible amount. Secretion of slime by developing eggs of marine animals may be considered a mechanism for temporarily escaping unfavorable conditions.

A single freshly hatched sole larva contained as much as $85.2 \%, 79.0 \%$ and $75.5 \%$ of the total energy contained in the fresh egg, at $10^{\circ}, 15^{\circ}$ and $20^{\circ} \mathrm{C}$, respectively. Thus, at hatching, net losses varied from $14.8 \%$ to $24.5 \%$ at these temperatures. Corresponding values reported by FAUSTOV \& ZOTIN (1964) are $2.0 \%$ for the stellate sturgeon Acipenser stellatus and $3.5 \%$ for the loach Misgurnus fossilis. A recalculation of LAASKER's (1962) data gives a value of $13.3 \%$ for the Pacific sardine Sardinops caerulea. Cumulative net efficiency of yolk utilization (after correcting for the remaining yolk) varied from about $68 \%$ to $47 \%$ at the test temperatures mentioned. These values are low in comparison to that $(78.7 \%$ ) of the Pacific sardine (LASKER 1962) but are close to those reported for the herring Clupea harengus by BLAXTER \& HEMPEL (1966). One possible reason for the low efficiency values obtained in sole larvae appears to be that, unlike in sardine larvae, the unused yolk mass undergoes considerable changes in its composition during embryonic development and it seems possible that the unused yolk mass of the sole larvae contained more energy than the values arrived at in the present study.

Hatching size and duration of the incubation period decrease with increasing temperature; this has been amply demonstrated also in other fish species by GRAY (1926, 1928), Kinne \& KInNe (1962) and SweET \& Kinne (1964). From the point of ecology it is interesting to note that the lower temperatures $\left(<7^{\circ} \mathrm{C}\right)$ arrest the development at different stages of development. This would suggest that the different sequences of embryonic events have different minimum temperature ranges. In the North Sea, the soles spawn during the spring when the water temperature gradually rises. If spawning occurs at a lower temperature $\left(<7^{\circ} \mathrm{C}\right)$, or if the water temperature decreases after spawning, egg development becomes arrested. Such "arrested eggs" do not die so quickly, however, and may continue to develop as soon as the temperature rises again. Since spawning time and surface temperature vary greatly from spawning place to spawning place and from year to year, initial body weights and sizes of freshly hatched larvae may vary accordingly.

\section{SUMMARY}

1. The eggs of Solea solea, like many other marine planktonic fish eggs, are characterized by a high water content $(91 \%$ ) and a relatively low calorific content (5800 cal/g dry organic substance). Demersal fish eggs, on the other hand, have, according to the information available from literature, a low water content (about $75 \%$ ) and a high calorific content $(6500 \mathrm{cal} / \mathrm{g}$ dry organic substance).

2. Older embryos and freshly hatched larvae of Solea solea secrete large quantities of slime upon brief exposure to distilled water; this makes the estimation of their dry weight and calorific content difficult. Slime secretion could be reduced to a certain extent by killing the larvae in $5 \%$ sea-water formalin prior to distilled water exposure (to remove adhering salt water). 
3. At $10^{\circ} \mathrm{C}$, incubation lasts 176 hours and freshly hatched larvae contain $85.2 \%$ of the energy contained in a freshly laid egg $(0.49 \mathrm{cal} / \mathrm{egg})$; at $15^{\circ} \mathrm{C}$ and $20^{\circ} \mathrm{C}$, the corresponding values are 80 hours, $79.0 \%$ and 53 hours, $75.5 \%$, respectively.

Acknowledgements: We are grateful to Professor O. Krnne for valuable suggestions and for improving our manuscript. One of us (T. J. P.) received the financial support from the DAAD (Bad Godesberg, Germany) during the course of this study.

\section{LITERATURE CITED}

Braxṫer, J. H. S. \& Hempel, G., 1966. Utilization of yolk by herring larvae. J. mar. biol. Ass. U. K. 46, 219-234.

Faustov, V. S. \& Zotin, A. I., 1964. Changes in the heat of combustion of the eggs of fishes and amphibians during development. Dokl. (Proc.) Acad. Sci. U.S.S.R. Biol. Sci. 162, 320-323 (Orig.: 965-968.)

FlüChTER, J,, 1966. Spawning, first feeding and larval behaviour of the North Sea sole. In: C. M. (Council Meeting) International Council for the Exploration of the Sea (I. C. E. S.) Sect. C: Near Northern Seas Committee 3, 1-5.

Gray, J., 1926. The growth of fish. 1. The relationship between embryo and yolk in Salmo fario. J. exp. Biol. 4, 215-225.

- 1928. The growth of fish. 2. The growth rate of the embryo Salmo fario. J. exp. Biol. 5, $110-124$.

Hartmann, M., Medem, F. Graf, Kühn, R. \& Bielig, H. J., 1947. Untersuchungen über die Befruchtungsstoffe der Regenbogenforelle. Z. Naturforsch. (B) 2, 330-349.

Hollet, A. \& Hayes, F. R., 1946. Protein and fat of the salmon egg as sources of energy for the developing embryo. Can. J. Res. (Ser. D) 24, 39-50.

KINNE, O. \& KINNE, E. M., 1962. Rates of development in embryos of a cyprinodont fish exposed to different temperature-salinity-oxygen-combinations. Can. J. Zool. 40, 231-253.

LASKER, R., 1962. Efficiency and rate of yolk utilization by developing embryos and larvae of the Pacific sardine Sardinops caerulea (Grard). J. Fish. Res. Bd. Can. 19, 867-875.

MeNGI, T., 1965. Veränderungen in der chemischen Zusammensetzung des reifenden Ovariums des Ostseedorsches. Kieler Meeresforsch. 21, 107-121.

Needham, J., 1931. Chemical embryology. Vol. 1-3. Cambridge Univ. Press, London, 2021 pp.

Paffenhöfer, G.-A. \& Rosenthal, H., 1968. Trodkengewicht und Kaloriengehalt sich entwickelnder Heringseier. Helgoländer wiss. Meeresunters. 18, 45-52.

Pandian, T. J., 1968. Changes in chemical composition and calorific content of developing eggs of the slipper limpet Crepidula fornicata. (Unpubl.)

RYLAND, J. S. \& Nichols, J. H., 1967. Effect of temperature on the efficiency of growth of plaice prolarvae. Nature, Lond. 214 (5087), 529-530.

SMrTH, S., 1957. Early development and hatching. In: The physiology of fishes. Ed. by M. E. Brown. Academic Press, New York, 1, 323-359.

- 1958. Yolk utilization in fishes. In: Embryonic nutrition. Ed. by D. Rudnick. Univ. Press, Chicago, Ill.

Sverdrup, H. V., Johnson, M. W. \& Fleming, R. H., 1964. The oceans. Their physics, chemistry and general biology. Prentice-Hall, Englewood Cliffs, N. J., 1087 pp.

SWEET, J. G. \& KINNE, O., 1964. The effects of various temperature-salinity combinations on the body form of newly hatched Cyprinodon macularius (Teleostei). Helgoländer reiss. Meeresunters. 11, 49-69. 